\title{
ANALISIS SISTEM INFORMASI AKUNTANSI ALUR PEMBAYARAN BIAYA KULIAH DI MASA PANDEMI COVID-19
}

\author{
Winda Anggraini ${ }^{1}$, Diah Intan Syahfitri, M. Acc ${ }^{2}$, Ahmad Jibrail ${ }^{3}$
}

\author{
${ }^{1 *}$ Fakultas Ekonomi dan Bisnis Universitas Teknologi Sumbawa \\ ${ }^{2}$ Fakultas Ekonomi dan Bisnis Universitas Teknologi Sumbawa \\ *Corresponding Author email:
}

winda.anggraini@uts.ac.id, diah.intan.syahfitri@uts.ac.id, ahmad.jibrail@uts.ac.id

\begin{tabular}{ll}
\hline & Abstrak \\
\cline { 2 - 3 } $\begin{array}{l}\text { Diterima : } \\
\text { Bulan Januari }\end{array}$ & Penelitian ini bertujuan untuk mengetahui dan menganalisis sistem informasi akuntansi \\
2021 & Alur Pembayaran Biaya Kuliah dimasa Pandemi Covid-19 di Univeristas Teknologi \\
& Sumbawa. Metode yang digunakan dalam peneltian ini adah metode deskriptif \\
& kualitatif. Adapun narasumber dari peneltian ini diantaranya Wakil Rektor 2 Bidang \\
& Keuangan tepatnya Direktorat Administrasi Keuangan Universitas Teknologi Sumbawa. \\
Diterbitkan : & Karyawan yang menjadi informan pada penelitian ini Direktur Keuangan, Bendahara \\
Bulan Februari & Universitas, dan Sub.Direktorat Administrasi Keuangan. Sumber data penelitian ini \\
2021 & adalah primer dan sekunder, dengan metode pengumpulan data menggunakan teknik \\
& wawancara, dokumentasi dan observasi. Hasil dari penelitian ini menunjukan bahwa \\
Keyword: & Sistem Informasi Akuntansi Alur Pembayaran Biaya Kuliah dimasa Pandemi Covid- 19di \\
Sistem Informasi & Universitas Teknologi Sumbawa telah dilakukan secara efektif dan efisien. Hal tersebut \\
Akuntansi, Alur & dapat dilihat berdasarkan data, prosedur, infrastruktur dan perangkat lunak yang ada serta \\
Pembayaran & sumber daya manusia yang bertanggung jawab dan kompeten. Dengan adanya Alur \\
Biaya Kuliah, & pembayaran biaya kuliah di masa pandemi Covid-19 secara online dapat \\
& membantu Sub. Direktorat Administrasi Keuangan bekerja dengan tetap melakukan \\
& social distancing sehingga alur pembayaran tersebut dapat diterapkan hingga saat ini. \\
\hline
\end{tabular}

\section{PENDAHULUAN}

Sistem informasi akuntansi adalah Susunan dari berbagai macam dokumen, catatan, peralatan termasuk komputer dan perlengkapannya, alat komunikasi, tenaga pelaksana serta seluruh laporan yang didesain untuk mentransformasikan data keuangan menjadi informasi yang dibutuhkan oleh manajemen Nugroho Widjajanto (2001).

Setiap perusahaan/instansi dituntut untuk menerapkan sistem akuntansi yang sesuai dengan kondisi masing-masing perusahaan/instansi. Sistem informasi akuntansi menjadi salah satu tolak ukur keberhasilan suatu perusahaan/instansi dan organisasi yang sedang berjalan. salah satu keberhasilan sebuah perusahaan/ instansi dengan menggunakan sistem Informasi Akuntansi yang diakui. Romney dan Steinbart (2006) juga menerangkan bahwa "sistem informasi akuntansi adalah Sebuah sistem yang mengumpulkan, mencatat, menyimpan, dan juga memproses data menjadi informasi yang berguna dalam membantu proses pengambilan keputusan".

Universitas adalah suatu Perguruan Tinggi yang bertujuan untuk menyelenggarakan pendidikan akademik yang Apabila sudah memenuhi syarat, universitas tersebut dapat menyelenggarakan sebuah pendidikan profesi. Universitas tersebut juga dapat menyelenggarakan kegiatan atau aktivitas dalam hal pendidikan yang sangat luas. Apabila universitas telah memenuhi syarat dan kewajibanya, maka setelahnya mahasiswalah yang memenuhi kewajibannya setelah mengikuti serangkaian aktivitas perkulihan, mahasiswa diwajibkan membayar DPP (Dana Pembinaan Pendidikan) dan SPP (Sumbangan Pembinaan pendidikan) yang nantinya dikelolah oleh pihak universitas untuk mendukung seluruh kegiatan perkuliahan.

Namun pada saat ini segala aktivitas terhadap manusia dibatasi dengan penerapan social distancingatau kata lain menjauhi kerumunan, menghindari pertemuan masal dan jaga jarak dari orang lain. hal tersebut terjadi karena saat ini sedang menggemparkan seluruh dunia PandemiCovid-19 yaitu penyakit yang disebabkan oleh infeksi virus

SARS-CoV-2 dimana pertama kali diidentifikasi di kota Wuhan, di provinsi Hubei Cina Desember 2019. Dengan adanya virus tersebut salah satu yang terkena dampaknya adalah dunia pendidikan, baik itu PAUD/TK, Sekolah tingkat dasar, sekolah tingkat menengah, sekolah tingkat akhir maupun perguruan tinggi (www.covid19.go.id).

Salah satu yang menerapkan aturan pemerintah tentang perkulihan dan segala aktivitas lembaga pendidikan pada masa pandemi Covid-19 adalah Universitas Teknologi Sumbawa yang merupakan lembaga pendidikan tinggi Swasta yang berada di Nusa tenggara barat tepatnya pulau Sumbawa. Berdasarkan hasil wawancara dengan 
bagian bendahara universitas bahwa pada saat ini dengan pembatasan social descanting kami kesulitan dan ketakutan terhadap penerimaaan kas yang masuk salah satunya dari pembayaran DPP dan SPP Mahasiswa. Sehingga universitas ini harus mempunyai Sistem Informasi Akuntansi alur pembayaran yang baik karena banyaknya penerimaan kas dari kegiatan pembayaran tersebut. Untuk itu penulis ingin melakukan analisis lebih dalam bagaimana sistem informasi akuntansi alur pembayaran Biaya kuliah pada masa Pendemi Covid-19.

Berdasarakan uraian di atas, peneliti berpandangan bahwa sistem informasi akuntansi alur pembayaran biaya kuliah pada pembayaran DPP dan SPP sangat penting dalam mendukung aktivitas operasional Universitas. Maka peneliti tertarik untuk melakukan penelitian tentang "Analisis Sistem Informasi Akuntansi Alur Pembayaran Biaya Kuliah dimasa Pandemi Covid-

19 (Studi Kasus Univeristas Teknologi Sumbawa)".

\section{LANDASAN TEORI}

\section{Sistem}

\section{Pengertian Sistem}

Sistem secara umum dapat didefinisikan sebagai kumpulan hal atau elemen yang saling bekerja sama atau yang dihubungkan dengan caracara tertentu sehingga membentuk satu kesatuan untuk melaksanakan suatu fungsi guna mencapai suatu tujuan. Sistem mempunyai karakteristik atau sifat - sifat tertentu, yaitu : Komponen Sistem, Batasan Sistem, Lingkungan Luar Sistem, Penghubung Sistem, Masukan Sistem, Keluaran Sistem, Pengolahan Sistem dan Sasaran Sistem. (Edhy Sutanta, 2009: 4). Menurut Jogiyanto,2005,1 (Dalam Buku Analisa dan Desain Sistem Informasi) Sistem adalah suatu jaringan kerja dari prosedur-prosedur yang saling berhubungan, berkumpul bersama-sama untuk melakukan suatu kegiatan atau untuk menyelesaikan suatu sasaran yang tertentu.

\section{Informasi}

\section{Pengertian Informasi}

Secara etimologi, informasi berasal dari bahasa Perancis kuno informacion

$$
\text { diambil dari bahasa latin }
$$
informationem yang berarti "garis besar, konsep, ide". Informasi merupakan kata benda dari informare yang berarti aktivitas dalam "pengetahuan yang dikomunikasikan". Informasi juga dapat diartikan sebagai data yang telah diolah menjadi bentuk yang lebih berguna dan lebih berarti bagi yang menerimanya.

\section{Akuntansi}

Menurut Soemarsono S.R (2004) Akuntansi adalah proses mengidentifikasikan, mengukur dan melaporkan informasi ekonomi untuk memungkinkan adanya penilaian dan keputusan yang jelas dan tegas bagi mereka yang menggunakan informasi tersebut.

\section{Sistem Informasi Akuntansi}

\section{Pengertian Sistem Informasi Akuntansi}

Menurut Bodnar dan Hopwood (2010) Sistem Informasi akuntansi adalah "Kumpulan dari berbagai macam sumber daya yaitu manusia dan juga peralatan yang memang dibuat untuk mengubah data keuangan dan juga data lainnya menjadi sebuah informasi yang berguna bagi penggunanya". Sedangkan menurut Nugroho Widjajanto (2001) adalah "Susunan dari berbagai macam dokumen, catatan, peralatan termasuk komputer dan perlengkapannya, alat komunikasi, tenaga pelaksana serta seluruh laporan yang didesain untuk mentransformasikan data keuangan menjadi informasi yang dibutuhkan oleh manajemen".

\section{Flowcart}

Tabel 2.1 Simbol Bagan Alir (Flowchart) Dokumen.

\begin{tabular}{|c|c|c|}
\hline Simbol & Nma & Penjelaran \\
\hline \multicolumn{3}{|c|}{ Simbollnputoutput } \\
\hline & Dohimen & $\begin{array}{l}\text { Doisme atan lapocan } \\
\text { dektrotik atus kertss. }\end{array}$ \\
\hline
\end{tabular}

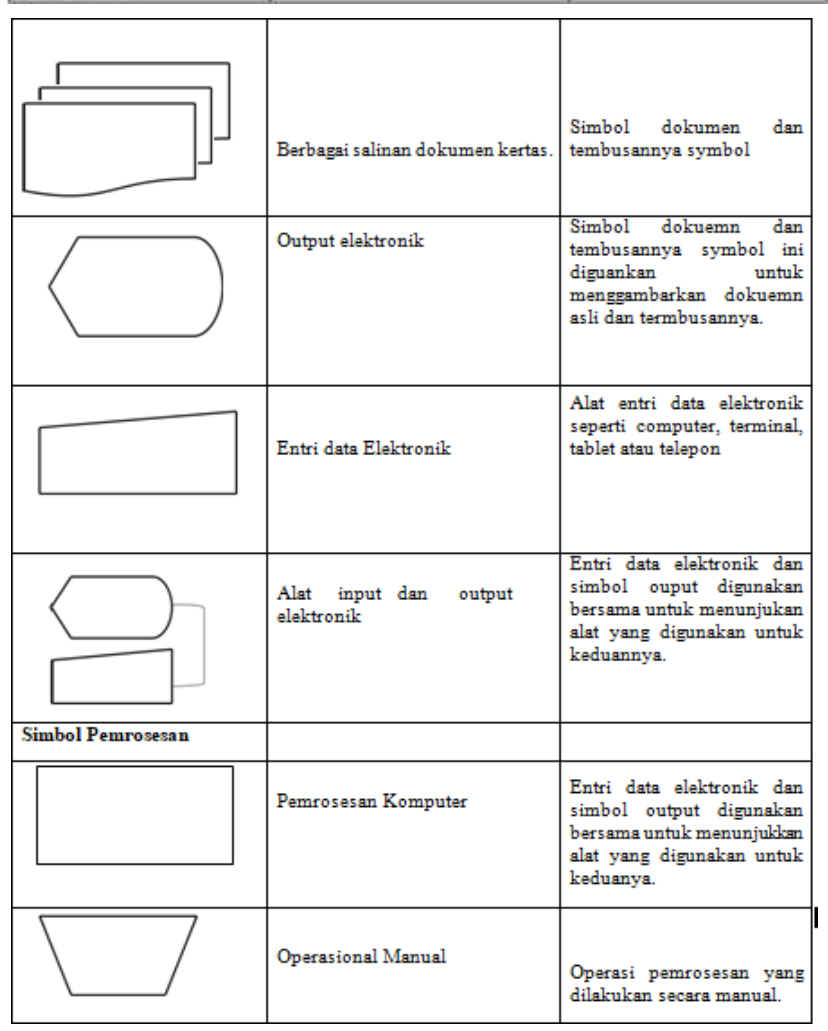




\begin{tabular}{|c|c|c|}
\hline Siahol Peogrimpanaz & & \\
\hline & Dutatase & 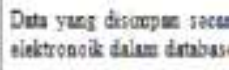 \\
\hline & Pita magretis & 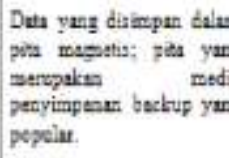 \\
\hline & Arsį seccentura & 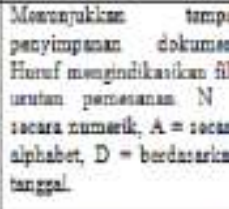 \\
\hline & Assig parmuras & 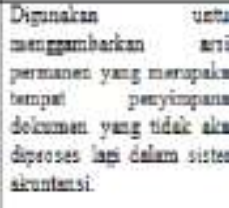 \\
\hline & hrmal/Boks Bessr & 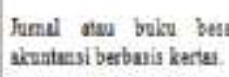 \\
\hline \multicolumn{3}{|c|}{ Sienbal arus dan bielain } \\
\hline & Arus doicomen atses peratosesta & 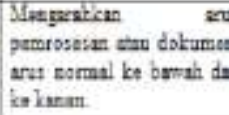 \\
\hline
\end{tabular}

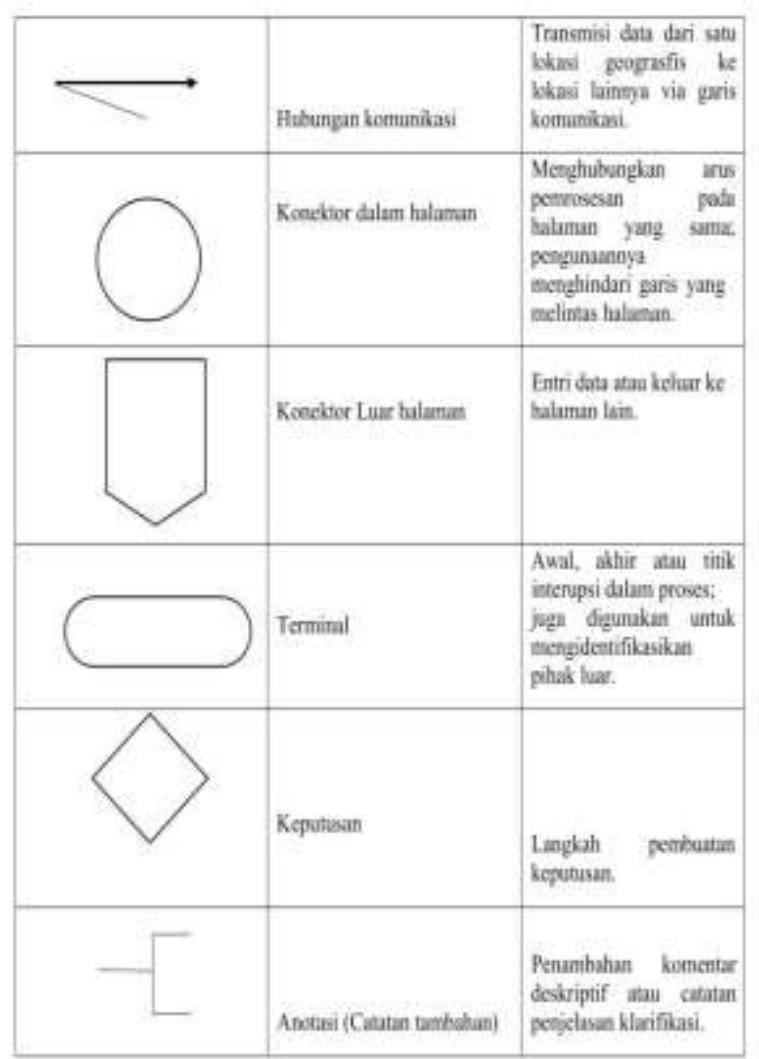

(Sumber : Romney, 2014 dan Mulyadi, 2010)

\section{Penelitian terdahulu}

Tabel 2.2 Rangkuman Penelitian Terdahulu

\begin{tabular}{|c|c|c|c|}
\hline No & Penelinat & Jual & Hand \\
\hline 1 & 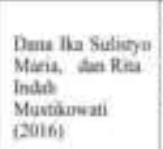 & 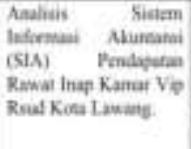 & 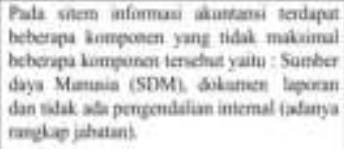 \\
\hline 2 & $\begin{array}{l}\text { Mayer Lilis Tanta } \\
\text { (2yi) }\end{array}$ & 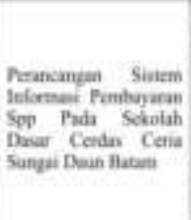 & 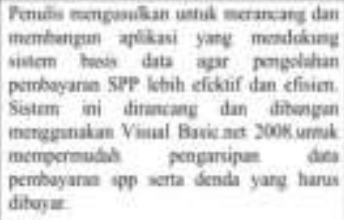 \\
\hline 5 & $\begin{array}{l}\text { Bernuatas Deti } \\
\text { Lapenas }\end{array}$ & 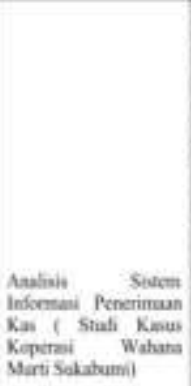 & 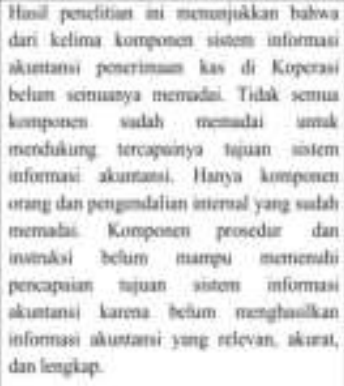 \\
\hline
\end{tabular}

\section{Kerangka Konseptual}

Penelitian ini menggunakan rancangan studi kasus pada Universitas teknologi Sumbawa.Menurut Haryani (2014: 37) Studi kasus yaitu melakukan penelitian terhadap objek tertentu yang populasinya terbatas, sehingga hasil kesimpulan yang diambil dari penelitian ini hanya berlaku bagi objek yang diteliti dan berlaku daribulan Maret 2020 hingga bulan Agustus 2020.

\section{Kerangka Konseptual Penelitian}

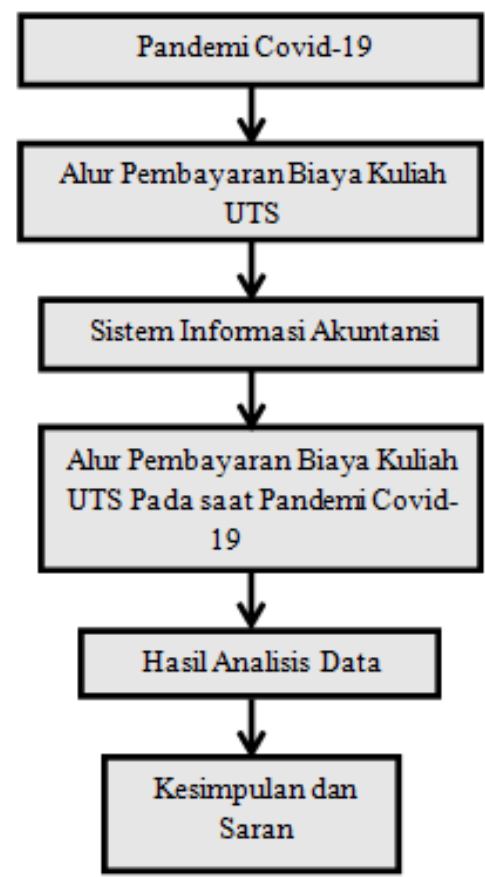

Gambar 3.1 kerangka konseptual 


\section{METODE PENELITIAN}

\section{Jenis Penelitian}

Jenis penelitian ini adalah deskriptif, dengan mengguanakan pendekatan kualitatif. Penelitian deskriptif memiliki tujuan untuk membuat deskripsi, gambaran secara sistematis, akurat mengenai fakta-fakta, sifat-sifat serta hubungan antar fenomena yang terdapat pada riset yang dilakukan. Penelitian ini dengan pendekatan kualitatif adalah suatu pendekatan penelitian yang menggunakan data berupa kalimat tertulis maupun lisan, perilaku, peristiwa-peristiwa, pegetahuan atau objek studi Sugiono, (2012:54). Pada penelitian ini bertujuan untuk mengetahui bagaimana sistem informasi akuntansi alur pembayaran biaya kuliah di masa pademi Covid- 19.

\section{Objek Penelitian}

Objek penelitian sistem informasi akuntansi alur pembayaran biaya kuliah di masa pademi Covid-19 di Universitas Teknologi Sumbawa, yang d imana Universitas Teknologi Sumbawa merupakan salah satu Universitas yang berada di pulau Sumbawa tepatnya di jalan raya Olat Maras Dusun Batu Alang Kecamatan Moyo Hulu Kabupaten Sumbawa.

\section{Subjek Penelitian}

Subjek dalam penelitian ini adalah bagianbagian yang terkait dalam sistem informasi akuntansi alur pembayaran biaya kuliah, seperti, bendahara umum universitas, Direktur keuangan,serta staf Sub Direktorat Administrasi Keuangan.

\section{Jenis dan Sumber Data}

Jenis data yang digunakan dalam penelitian ini adalah data kualitatif seperti Jumlah Mahasiswa berbayar, prosedur pembayaran dan data lainnya yang diperlukan. Sumber data yang digunakan dalam penelitian ini:

Data primer

Menurut Sugiono (2011) data primer merupakan sumber data yang lansung. Dalam penelitian ini data yang diperoleh melalui hasil wawancara dengan bendahara umum universitas dan staf Sub Direktorat Admnistrasi Keuangan. Data berupa jumlah mahasiswa berbayar, prosedur pembayaran dan data yang diperlukan., serta data pendukung lainnya pada direktorat administrasi keuangan.

Data sekunder

Menurut Patilima (2011) data skunder merupakan sumber data penelitian yang diperoleh peneliti secara langsung melalui media perantara. Data sekunder umumnya yang telah tersusun dalam arsip (data dokumenter) yang dipublikasikan dan yang tidak dipublikasikan. Dalam penelitian ini data yang diperoleh dari data sekunder berupa, studi literature melalui hasil penelitian sebelumnya, browsing di internet, serta buku-buku yang menyangkut teori-teori yang relevan dengan masalah yang dibahas.

\section{Metode Pengumpulan Data \\ Observasi}

Nasution dalam Sugiono (2011) observasi adalah fakta mengenai dunia kenyataan yang diperoleh melalui observasi yaitu dengan cara pengamatan lansung pada Loket pembayaran administarsi keuangan Universitas Teknologi Sumbawa.

\section{Wawancara}

Esterberg dalam Sugiono (2011) wawancara merupakan pertemuan antara dua orang untuk bertukar informasi dan ide melalui tanya jawab,yaitu dengan cara wawancara dengan bendahara umum universitas, Direktur Keuangan dan Staf Sub Direktorat Administrasi Keuangan.

\section{Dokumentasi}

Menurut Sugiono dokumentasi adalah peristiwa yang sudah berlalu. Dokumen bisa berbentuk tulisan, gambar, atau karya-karya monumental dari seseorang. Dokumen yang berbentuk tulisan misalnya catatan harian, sejarah. Dalam penelitian ini data yang diambil adalah sejarah berdirinya, jumlah mahasiswa berbayar, prosedur pembayaran dan data pendukung lainnya.

\section{Teknik Analisis Data}

Adapun teknik analisis data yang digunakan oleh peneliti dalam penelitian ini yaitu menganalisis data yang terkumpul dari berbagai sumber yang kemudian siap di kelola. Berikut tahapan peneltian yang digunakan:

1. Pengumpulan data, dimana data yang dimaksud adalah mencatat hasil wawancara dengan pihak dibagian Sub Direktorat Administrasi Keuangan Universitas Teknologi Sumbawa. Dokumentasi juga pada tahap pengumpulan data ini yang berupa jumlah mahasiswa berbayar, prosedur pembayaran dan data pendukung lainnya.

2. Reduksi data, Setelah data terkumpul, peneliti melakukan reduksi data yaitu dengan cara melakukan pemilihan data hasil wawancara, observasi, dan dokumentasi. Karena hasil data yang peroleh peneliti masih mentah, maka peneliti akan memilih data yang benar-benar ada kaitannya dengan Sistem informasi akuntansi alur pembayaran biaya kuliah.

3. Penyajian data, dimana pada tahap ini data disajiakan dalam bentuk uraian singkat tentang Sistem infromasi akuntansi alur pembayaran biaya kuliah.

4. Analisis data, pada tahap ini peneliti menganalisis Sistem infromasi akuntansi alur pembayaran biaya kuliah.

5. Kesimpulan, tahap terakhir yaitu peneliti menarik kesimpulan. 


\section{Alat Analisis Data}

Alat analisa yang penulis gunakan dalam penelitian ini adalah teori-teori dalam buku sistem informasi akuntansi, yaitu pada buku Sistem Informasi Akuntansi yang ditulis oleh Mardi tahun 2014 dan Sistem Informasi Akuntansi.

Edisi 13 ditulis oleh Marshall B. Romney dan Paul John Steinbart tahun 2014. Dalam alat analisa tersebut terdapat komponen dan indikator yang dijadikan tolak ukur untuk menilai sistem informasi Alur Pembayaran Biaya Kuliad dimasa Pandemi Covid-19. Adapun komponen dan indikator tersebut, yaitu :

Tabel 3.1Indikator cara menilai Komponen Sistem Informasi Akuntansi Alur Pembayaran Biaya Kuliah di masa Pandemi Covid-19 Universitas Teknologi Sumbawa

\begin{tabular}{|c|c|c|}
\hline No & $\begin{array}{l}\text { Kompoeses } \\
\text { Sistem } \\
\text { Infurmas } \\
\text { Akumansi }\end{array}$ & Indikater \\
\hline 1 & $\begin{array}{l}\text { Sanber Daya } \\
\text { Manaid } \\
\text { (SDM) }\end{array}$ & 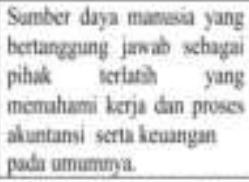 \\
\hline 2 & Prosedar & $\begin{array}{l}\text { Adanya tab can proses } \\
\text { petcatalan yang bersumber } \\
\text { dari tratralssi, jumal, buku } \\
\text { besir, neraca sampai dengan } \\
\text { lapeea ksaanga. }\end{array}$ \\
\hline 3 & Dana & 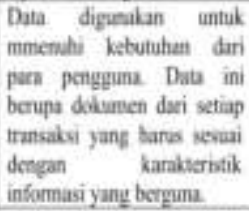 \\
\hline 4 & $\begin{array}{l}\text { Infrastiktar } \\
\text { Texhologi } \\
\text { Infismasi dan } \\
\text { Perangkat } \\
\text { Lunak }\end{array}$ & $\begin{array}{l}\text { Insfratruktur Teknologi } \\
\text { imfonmaai dan perangkat } \\
\text { lunak yang digunakan untuk } \\
\text { membuntu peoses } \\
\text { pesgolahan data. }\end{array}$ \\
\hline
\end{tabular}

( Sumber : Romney 2014 dan Mardi 2014)

\section{HASIL DAN PEMBAHASAN}

\section{Sejarah dan Profil Universitas Teknologi Sumbawa}

Sejarah diawali dengan berdirinya Sekolah Tinggi Teknologi Teknik Sumbawa (ST3S) pada tanggal 21 Mei 2012. Sekolah ini merupakan sekolah tinggi teknik pertama di pulau Sumbawa. ST3S berada di bawah naungan Yayasan Dea Mas, pada saat berdirinya memiliki 4 Program studi yakni program studi teknik metalurgi, program studi teknik mesin, program studi teknik informatika, dan program studi teknobiologi. Berdirinya sekolah ini diinisiasi oleh Zulkieflimansyah yang saat itu menjadi anggota Dewan Perwakilan Rakyat Republik Indonesia yang juga berasal dari Sumbawa

Pendirian ST3S dilatarbelakangi oleh besarnya potensi sumber daya alam Kabuputen Sumbawa berupa sumber daya mineral, pertanian, perkebunan dan perikanan, sementara ketersediaan tenaga profesional di bidang keteknikan masih rendah. Untuk itulah ST3S membuka program studi yang relatif langka di provinsi Nusa Tenggara Barat maupun di kawasan Indonesia Timur.Tidak lama setelah mendirikan ST3S, yayasan yang sama kembali menginisiasi institusi pendidikan baru yang dinamakan Sekolah Tinggi Ilmu Ekonomi (STIE) Sumbawa. STIES didirikan dengan harapan dapat menjadi solusi atas tingginya kebutuhan terhadap profesional di bidang manajemen dan keuangan. STIES rencananya akan menyelenggarakan pendidikan strata satu dengan dua program studi, yakni program studi akuntansi dan program studi manajemen keuangan.

Dalam proses pengajuan izin ke Direktorat Jenderal Pendidikan Tinggi Kementerian Pendidikan dan Kebudayaan, Yayasan Dea Mas mengajukan izin pendirian ST3S dan STIES secara bersamaan. Atas saran dari Dikti, selanjutnya ST3S dan STIES digabungkan usulan perizinannya menjadi Universitas, yang kemudian dinamakan Universitas Teknologi Sumbawa (UTS).

Setelah melalui seluruh tahapan dan ketentuan yang menjadi syarat izin pendirian sebuah perguruan tinggi, pada tanggal 14 Maret 2013, diterbitkanlah keputusan Menteri Pendidikan dan Kebudayaan Republik Indonesia Nomor 65/E/O/2013 tentang Ijin Pendirian Universitas Teknologi Sumbawa di Kabupaten Sumbawa, Provinsi Nusa Tenggara Barat pada tanggal 22 April 2014 Mendikbud RI mengeluarkan Surat Nomor 65/E/O/2014 yang ditujukan kepada Yayasan Dea Mas sebagai penyelenggara. Dosen dan mahasiswa UTS berdatangan dari seluruh penjuru tanah air dari Sabang sampai Merauke. Dosen-dosen yang berkualitas lulusan dalam dan luar negeri berjumlah 70 orang dan mengajar mahasiswa yang berjumlah 1376 orang dan akan bertambah terus setiap tahunnya. Universitas Teknologi Sumbawa terdiri dari 6 Fakultas yaitu Fakultas Ekonomi dan Bisnis, Fakultas Ilmu Komunikasi, Fakultas Psikologi, Fakultas Teknologi Pertanian, Fakultas Teknik, Fakultas Teknobiologi dan 15 Program Studi terdiri dari Program studi Akuntansi, Manajemen, Ekonomi Pembangunan, Ilmu Komunikasi, Psikologi, Teknologi Hasil Pertanian, Teknologi Industri Pertanian, Teknik Informatika, Teknik Metalurgi, Teknik Elektro, Teknik Sipil, Teknik Industri, Teknik Mesin, Teknobiologi dan Manajemen Inovasi.

Saat ini Universitas Teknologi Sumbawa dipimpin oleh Chairul Hudaya, Ph.D, seorang Doktor muda lulusan dari University of Science and Technology - Korea Institute of Science and Technology. Universitas Teknologi Sumbawa berkembang dengan cepat bila dilihat dari usia berdirinya. Banyak kerjasama diadakan dengan institusi-institusi dari dalam dan luar negeri untuk 
menunjang kualitas civitas akademikanya. Banyak beasiswa yang diselenggarakan oleh Universitas Teknologi Sumbawa untuk para dosen dan mahasiswa agar kualitas SDM semakin baik. Pada tahun 2016 telah terbentuk Program Magister Teknologi yang menguatkan Universitas Teknologi Sumbawa sebagai Perguruan Tinggi berbasis teknologi di belahan Indonesia bagian timur. Tepatnya pada September 2017 terbentuk Program Magister Manajemen Inovasi yang sudah berjalan sampai sekarang dan sudah memiliki 4 angkatan.

\section{Analisis Data}

Universitas Teknologi Sumbawa hingga saat ini telah berdir selama 8 tahun, dengan mahasiswa aktif berjumlah 3.898 yang berasal dari berbagai macam kota dan provinsi di Indonesia. Mahasiswa UTS memiliki status pembayaran yang berbeda-beda. Ada mahasiswa yang berbeasiswa dan ada mahasiswa dengan status berbayar. Mahasiswa beasiswa adalah mahasiswa yang terbebas dari kewajiban pembayaran biaya kuliah.sedangkan mahasiswa berbayar adalah mahasiswa yang memiliki kewajiban untuk membayar biaya kuliah berupa SPP dan DPP.

Jumlah mahasiswa reguler atau berbayar sebanyak 3.337 orang sehingga penerimaan kas yang diterima per harinya cukup besar. Misalnya jika ada 20 saja mahasiswa yang melakukan pembayaran biaya kuliah secara cash dengan nominal 2 juta, maka uang yang diterima di loket pembayaran sebesar 40 juta rupiah. Hal tersebut cukup menyulitkan staf keuangan untuk melakukan proses pembayaran. Dengan banyaknya jumlah uang yang diterima oleh direktorat keuangan mahasiswa membawa uang cash ke loket pembayaran dan mengisi kuitansi pembayaran. Setelah itu Staf Sub Direktorat Administrasi Keuangan menghitung jumlah uang yang diberikan oleh mahasiswa. Staf sub direktorat keuangan mengambil kuitansi yang berwarna putih, dan memberikan kuitansi yang berwarna pink kepada mahasiswa. Setelah itu staf Sub Direktorat Administrasi Keuangan menginput data pembayaran di Excel dan menyerahkan kuitansi kepada bendahara untuk di data oleh bendahara pada penerimaan kas SPP dan DPP.

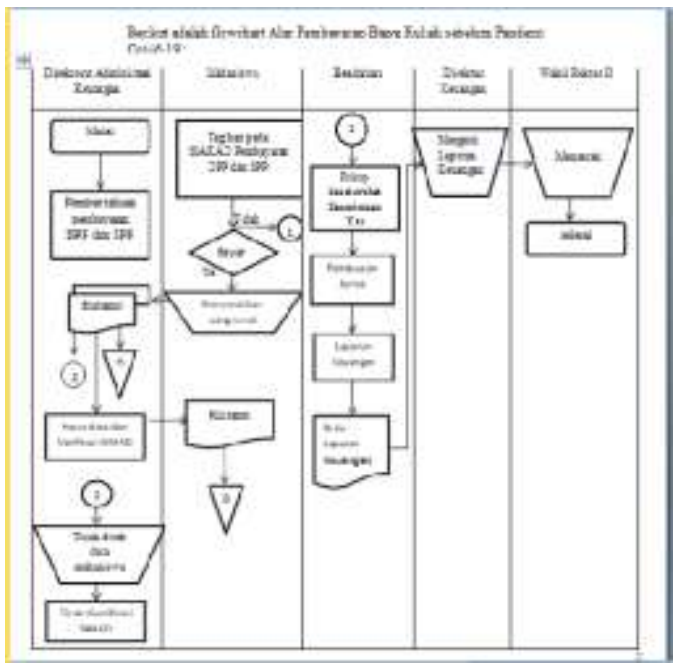

Gambar 4.1 Flowchart sistem informasi Akuntansi Alur Pembayaran biaya kuliah sebelum Pandemi Covid-19

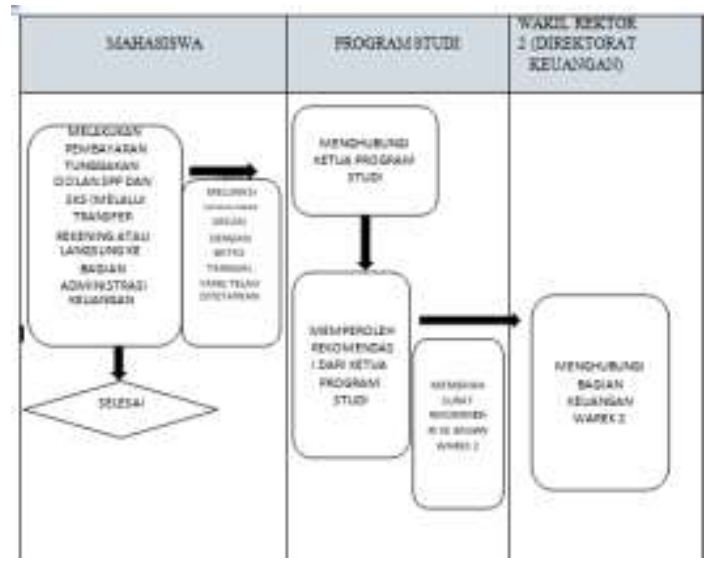

Gambar 4.2 Alur pembayaran biaya kuliah sebelum pandemi Covid-19

Mahasiswa berbayar melakukan kewajiban pembayaran Biaya Kuliah Baik SPP maupun DPP pada waktu masuk semester baru dan sebelum Ujian Akhir Semester. Seperti yang disampaikan oleh Ibu Nurfadliah melalui wawancara:

"Biasanya pembayaran biaya kuliah mahasiswa itu sebelum KRS sama sebelum UAS, mahasiswa harus sudah bayar ".

Sebelumnya mahasiswa mendapatkan pemberitahuan untuk membayar SPP dan DPP berupa tagihan yang harus dibayar di SIAKAD. Mahasiswa mendatangi Loket pembayaran Direktorat Administrasi Keuangan yang semula namanya adalah BAUK. Mahasiswa datang untuk melakukan proses pembayaran biaya kuliah secara tunai dan menyerahkan buku pembayaran. Sub Direktorat Administrasi Keuangan akan membuat dua kuitansi sebagai bukti adanya transaksi yang terjadi. Dua Kuitansi tersebut yang pertama untuk bagian keuangan dan bendahara dan kuitansi kedua diberikan untuk mahasiswa. Kuitansi yang dipegang Oleh Direktorat Administrasi Keuangan selanjutnya di input pembayaran dan melakukan 
Verifikasi SIAKAD mahasiswa yang bersangkutan tersebut. Sedangkan mahasiswa yang tidak melakukan pembayaran, Direktorat Administrasi Keuangan secara otomatis tidak melakukan proses pengecekan dan selanjutnya SIAKAD mahasiswa tersebut tidak dilakukan proses verifikasi.

Hasil Observasi penulispun selama proses penelitian sama dengan penjelasan dari Ibu Nurfadliyah mengenai proses pembayaran tersebut dalam wawancara dengan mahasiswa, yaitu : "mahasiswa yang mau bayar uang kuliah itu kalo mahasiswa berbayar langusng aja ke loket pembayaran Direktorat Administrasi Keuangan. Habis itu saya disuruh isi kuitansi, nanti yang putih buat yang diloket yang pink untuk kita mahasiswa, kalo sudah sesuai kita bayar baru da di verifikasi SIAKAD kita”.

Bagian bendahara merekap seluruh penerimaan kas Universitas baik pembayaran SPP maupun DPP setiap akhir bulan penerimaan kas pada komputer kemudian Direktur keuangan membuat jurnal, buku besar sampai laporan keuangan melalui komputer yang memiliki aplikasi pengelolahan Akuntansi. Seperti yang disampikan oleh Ibu Nada Fa'adhila dalam wawancara sebagai berkut :

"Direktorat Administrasi Keuangan itu berikan ke saya uang dan kuitansi terus saya masukan ke komputer excel nanti disitu ada total seleruh penerimaan tadi saya masukkan ke buku besar untuk dijadikan laporan keuangan. Nanti diberikan ke direktur keungan setiap akhir bulan".

Laporan keungan tersebut nantinya akan dicek langsung oleh Wakil Rektor 2 bidang keuangan. Setelah selesai oleh Wakil Rektor2 laporan keuangan tersebut diberikan kepada Rektor Univeristas dan Yayasan yang menaungi univeristas sebagai bentuk pertanggungngjawaban pada bagian keuangan dan bendahara.

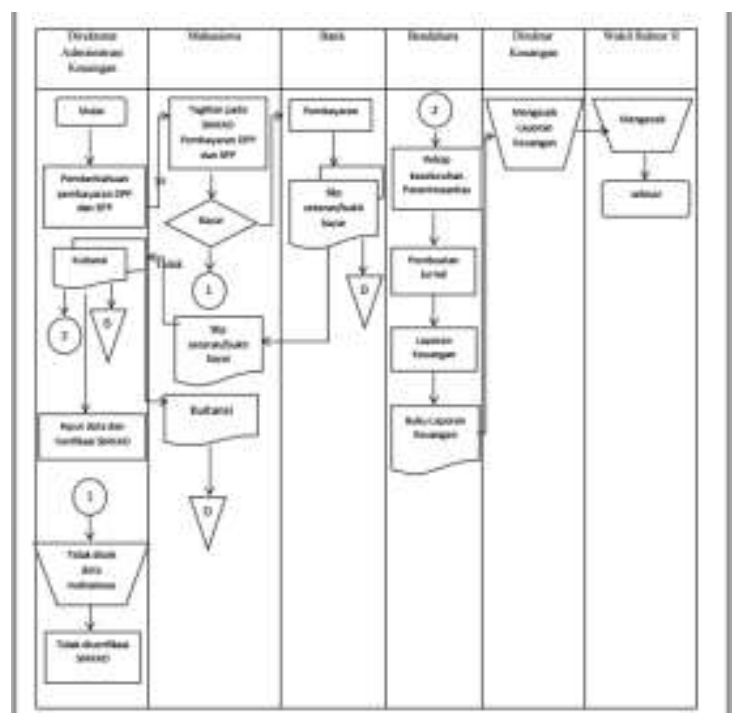

Gambar 4.3 Flowchart system informasi Akuntansi Alur Pembayaran biaya kuliah saat Pandemi Covid19

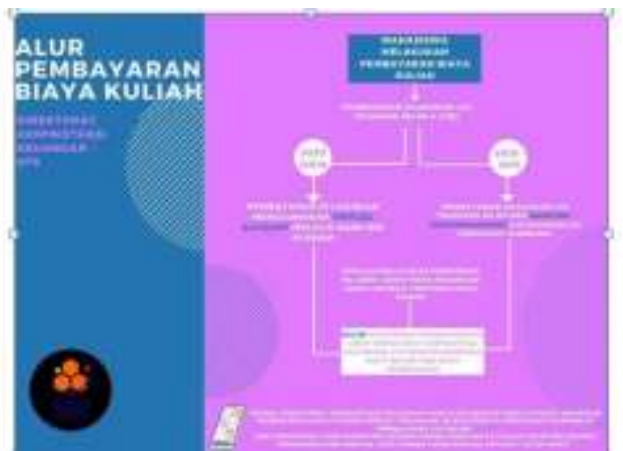

Gambar 4.4 Alur pembayaran biaya kuliah dimasa pandemi Covid-19

Pada flowchart kedua, adalah Sistem Informasi Akuntansi alur pembayaran biaya kuliah pada saat terjadinya pandemi COVID-19.Dimulai dari mahasiswa mendapatkan pemberitahuan untuk pembayaran biaya kuliah baik DPP maupun SPP berupa surat tagihan dari Direktorat Administrasi Keuangan. Mahasiswa dapat mengecek jumlah tagihannya di SIAKAD, setelah itu, mahasiswa melakukan pembayaran melalui transfer pada bank ke nomor rekening univeristas. Seperti yang dipaparkan oleh bagian Direktorat Administrasi keuangan pada saat wawancara berlangsung sebagai berikut :

"Prosesnya hampir sama sebenarnya, hanya saja yang membedakan sejak pandemic terjadi kami sudah tidak menerima pembayaran secara tunai. Nanti mahasiswa bayar ke bank transfer ke rekening kampus habis itu bukti bayarnya di serahkan ke loket pembayaran, terus setelah itu prosesnya sama di kasih ke bagian bendahara".

Semenjak terjadinya COVID - 19 untuk mencegah penularan virus tersebut Univeristas memutuskan sejak saat itu tidak lagi mahasiswa berbayar melakukan pembayaran secara tunai tetapi melalui bank dengan cara transfer ke rekening Universitasyang telah ditentukan oleh Direktorat Keuangan.

Pada saat melakukan pembayaran ke bank, pihak bank akan membuat slip bukti pembayaran dua rangkap. Slip yang pertama digunakan untuk bank dan slip kedua digunakan untuk mahasiswa, kemudian slip yang diberikan ke mahasiswa tersebut ditukarkan di loket pembayaran. Staf Sub Direktorat Administrasi Keuangan akan membuat dua kuitasi sebagai bukti adanya transaksi yang terjadi. Kuitansi pertama untuk bagian keuangan dan bendahara dan kuitansi kedua untuk mahasiswa. Dari kuitansi pertama nantinya Staf Sub Direktorat Administrasi Keuangan akanmelakukan input data dan melakukan verifikasi SIAKAD mahasiswa yang bersangkutan. Sama seperti flowcart sebelumnya, bagi mahasiswa yang tidak melakukan pembayaran, Sta Sub 
Direktorat Administrasi Keuangan otomatis tidak melakukan proses pengecekan dan selanjutnya SIAKAD mahasiswa tersebut tidak dapat diverifikasi oleh Staf SubDirektorat Administrasi Keuangan.

Bagian bendahara merekap seluruh penerimaan kas universitas khususnya pembayaran biaya kuliah SPP dan DPP setiap akhir bulan penerimaan kas pada komputer kemudian membuat jurnal, buku besar sampai laporan keuangan melalui komputer yang memiliki aplikasi pengolahan akuntansi. Laporan keuangan tersebut nantinya akan dicek oleh Direktur Keuangan sebelum dicek langsung oleh Wakil Rektor 2. Setelah itu wakil rektor 2 memberikan laporan tersebut kepada Rektor Universitas Teknologi Sumbawa dan yayasan yang menaungi universitas sebagai bentuk pertanggungjawaban khususnya pada bagian keuangan dan bendahara.

Mahasiswa yang tidak melakukan pembayaran biaya kuliah tidak diverifikasi data dan SIAKAD sehingga tidak bisa mengisi KRS dan mengikuti Ujian Akhir Semester.

\section{Analisis Sistem Informasi Akuntansi Alur Pembayaran Biaya kuliah dimasa pandemi Covid-19}

Berikut ini adalah hasil analisis system informasi akuntansi alur pembayaran biaya kuliah dimasa pandemi Covid-19 di Universitas Teknologi Sumbawa:

1. Sumber Daya Manusia

Sumber daya manusia di universitas khususnya dibagian wakil rektor 2 bidang keuangan harus memiliki kualitas yang minimal mempunyai pendidikan sarjana, pengalaman ataupun pihak terlatih yang memahami kerja karena universitas merupakan lembaga pendidikan jadi menggunakan standar pendidikan dalam menyeleksi sumber daya manusia yang akan dipekerjakannya untuk menunjang aktifitas universitas khususnya biaya kuliah. Ada dua staf Sub Direktorat Administrasi Keuangan yang melayani pembayaran dan satu pegawai yang melakukan pencatatan. Seperti yang disampaikan oleh Direktur Keuangan dalam kutipan wawancara berikut:

"di loket pembayaran itu ada dua orang yang melayani pembayaran mahasiswa".

Pegawai yang dimiliki universitas khususnya yang terlibat dalam aktivitas pembayaran biaya kuliah memiliki pendidikan terakhir sarjana yang sesuai.

Berdasarkan pemaparan tersebut kompenen sumber daya manusia yang terlibat dalam alur pembayaran biaya kuliah ini sudah dikatakan maksimal dalam mendukung proses pembayaran biaya kuliah.

2. Prosedur
Aktifitas dari prosedur di universitas yaitu ada bukti transaksi berupa kuitansi, rekap penerimaan kas, jurnal sampai laporan keuangan. Rekap dibuat setiap akhir bulan lalu dibuat jurnal sampai laporan keuangan menggunakan pengolahan data akuntansi yang sistematis, yang terlibat dalam proses ini juga termasuk Direktorat Administrasi Keuangan dan bendahara. Alur pembayaran biaya kuliah saat ini sudah baik dan rapi. Dari bukti transaksi yang masuk lalu dibuat jurnal, buku besar sampai laporan keuangan. Hasil observasi yang dilakukan penulis sama dengan apa yang disampaikan oleh staf Sub Direktorat Administrasi Keuangan dalam kutipan wawancara berikut :

"direktorat keuangan membuat surat tagihan cicilan 1 dan surat tagihan cicilan ke 2 untuk selanjutkan diinformasikan ke mahasiswa. Karena dimasa covid gini kan kita diharuskan untuk melakukan protocol kesehatan salah satu nya menjaga jarak.. system pembayarannya , jadi mahasiswa bayar via bank. Kita yang diloket tidak lagi pegang dan hitung uang cash - mahasiswa tukar bukti bayar atau transfer di loket keuangan sama kuitansi pembayaran UTS.Kita input pembayaran mahasiswa di data excel".

3. Data

Data atau dokumen yang digunakan pada universitas Teknologi Sumbawa cukup sederhana yaitu berupa Virtual Account, kuitansi dan Buku Pembayaran Mahasiswa. Kuitansi ditulis oleh mahasiswa yang melakukan pembayaran biaya kuliah yang isinya terdiri dari nama, nim, program studi, dan jumlah bayar mahasiswa yang bersangkutan. Kuitansi terdiri dari dua lapis lembaran berwarna putih dan pink, dimana kuitansi yang berwarna putih diambil oleh staf direktorat Administrasi Keuangan dan kuitansi warna pink diserahkan ke mahasiswa untuk disimpan sebagai bukti bahwa mahasiswa tersebut telah membayar biaya kuliah yang tertagihkan. Sedangkan untuk buku pembayaran mahasiswa diisi oleh Direktorat Administrasi Keuangan sebagai pegangan dan bukti mahasiswa bahwa telah melakukan pembayaran biaya kuliah berupa spp dan dpp. penerimaan kas pada pembayaran SPP dan DPP ini sudah dikatakan baik dalam menjadibukti transaksi penerimaan kas. Pada saat pandemi covid-19, Universitas menerapkan sistem pembayaran menggunakan virtual Account. Sehingga meningkatkan keakuratan data yang diperoleh pihak Sub Direktorat Administrasi Keuangan.

4. Infrastruktur Informasi Teknologi dan Perangkat Lunak 
Infrastruktur teknologi informasi dan perangkat lunak yang ada di universitas teknologi Sumbawa bertujuan untuk membantu para karyawan dalam mengolah data untuk menghasilkan suatu informasi. Universitas memiliki komputer dan juga aplikasi pengolahan data akuntansi yang otomatis yang digunakan setiap hari dalam melakukan pekerjaannya. Infrastruktur teknologi informasi dan perangkat lunak yang dimiliki oleh universitas telah memadai untuk membantu proses pengolahan data. Penulis juga melakukan observasi untuk melihat bagaimana penggunanan komputer dalam kerja yang dilakukan oleh BAUK dan bendahara. Hasil dari observasi pun sama dengan apa yang disampaikan oleh BAUK dan bendahara dalam wawancaranya. Berdasarkan pemaparan tersebut kompenen infrastruktur teknologi informasi dan perangkat lunak, adanya komputer yang digunakan untuk mengelola data maupun kerja yang dilakukan. Untuk komponen ini sudah dikatakan baik dalam mendukung proses pengolahan data menggunakan komputer sepenuhnya pada penerimaan kas.

\section{PENUTUP}

\section{Kesimpulan}

Analisis Sistem Informasi Akuntansi Alur Pembayaran Biaya Kuliah dimasa Pandemi Covid19di Universitas Teknologi Sumbawa telah dilakukan secara efektif dan efisien.Hal tersebut dapat dilihat berdasarkan Sumber Daya Manusia (SDM) yang bertanggung jawab dan kompeten, Prosedur pembayaran yang baik dan rapih, data berupa buku dan kuitansi pembayaran yang sangatmendukung keakuratan data, sertaInfrastruktur Teknologi Informasi dan perangkat lunak yang lengkap dan baik dalam menunjang berjalannya proses pembayaran biaya kuliah di Universitas Teknologi Sumbawa.
Dengan adanya Alur pembayaran biaya kuliah di masa pandemi Covid-19 secara online dapat membantu Sub Direktorat Administrasi Keuangan bekerja dengan tetap melakukan social distancing sehingga alur pembayaran tersebut dapat diterapkan hingga saat ini.

\section{Saran}

Sebagai akhir dari kajian ini penulis menyampaikan beberapa saran : Penerapan pembayaran biaya kuliah secara online yang efektif dan efisien maka sebaiknya dapat diterapkan secara berkelanjutan oleh Universitas Teknologi Sumbawa, walaupun masa pandemi covid-19 sudah teratasi.

\section{REFERENSI}

Anastasia, Diana L. S. 2011. Sistem Informasi Akuntansi, Perancangan, Prosedur dan Penerapan. Yogyakarta: Andi Yogyakarta.

Dana, Ika Maria. 2016. Analisis Sistem InformasiAkuntansi (SIA) Pendapatan Rawat Inap Kamar Vip Rsud Kota Lawang. Malang.

Harahap, S. S. 2013. Teori Akuntansi. Jakarta : Rajawali Pers.

Mulyadi. 2016, Edisi Keempat. Sistem Akuntansi. Jakarta: Salemba empat.

Soemarso. 2009, Edisi kelima. Akuntansi Suatu Pengantar. Jakarta: Salemba Empat.

Steinbart, M. B. 2014. Edisi 13. Sistem Informasi Akuntansi. Jakarta: Salemba Empat.

Sugiyono. 2012. Metode Penelitian Bisnis. Bandung: Alfabeta.

Sutabri, T. 2012. Analisis Sistem Informasi Akuntansi Penerimaan Dan Pengeluaran Kas Pada Pt. Hasjrat Abadi Manado. Manado: Andi Yogyakarta. 